\title{
Adult Subependymal Giant Cell Astrocytoma
}

National Cancer Institute

\section{Source}

National Cancer Institute. Adult Subependymal Giant Cell Astrocytoma. NCI Thesaurus.

Code C71017.

A subependymal giant cell astrocytoma occurring in adults. 